\title{
Modelli digitali interconnessi per ampliare la conoscenza e migliorare la fruizione del patrimonio costruito
}

Margherita Pulcrano

Abstract

II contributo riporta i primi esiti di una ricerca ancora in corso che intende indagare le connessioni tra diverse modalità di rappresentazione del patrimonio costruito: la nuvola di punti (ottenuta mediante tecnologie range-based), il modello informativo (derivante dall'applicazione della metodologia BIM) e la fruizione virtuale (con particolare interesse per la realtà virtuale). Caso studio sul quale sperimentare l'applicazione e verificare il processo ipotizzato, inteso come un workflow unico e continuo, è l'Hospital Simón Ruiz di Medina del Campo (Valladolid, Spagna), annoverato tra i più antichi edifici della città.

Parole chiave

Hospital Simón Ruiz, analisi geometrica, nuvola di punti, H-BIM, confronti.

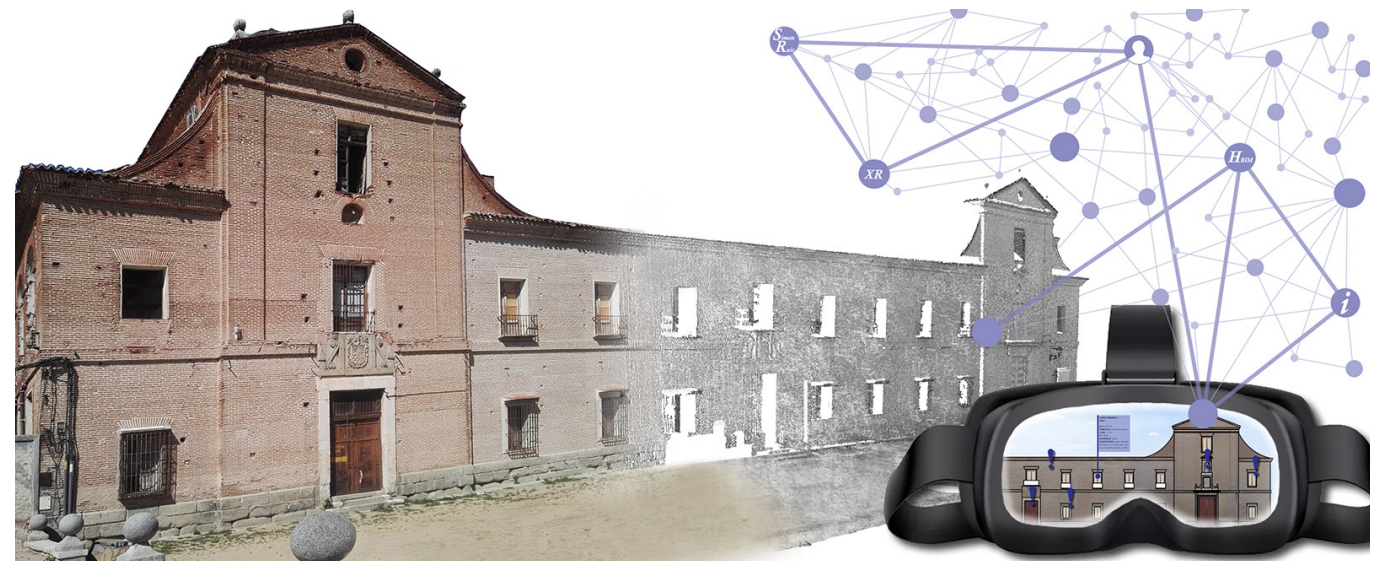




\section{Introduzione}

Oggigiorno, nell'era dell'Industria 4.0 e dell'loT (Internet of Things), il rischio di perdere il contatto con la realtà che ci circonda è davvero molto elevato. Dai rapporti personali mediati dai social media agli acquisti di beni e servizi, talvolta primari, tramite app o siti internet dedicati, non c'è aspetto avulso dall'utilizzo delle tecnologie digitali.

Anche il campo del Patrimonio Culturale non ne è immune. Sempre più spesso, infatti, modelli 3D iperrealistici emulano la realtà costruita - o prefigurata - con ricostruzioni minuziose degli aspetti e delle caratteristiche che la connotano. Attraverso specifici strumenti visione, questi modelli forniscono esperienze multisensoriali che tendono a travalicare l'ormai sottile confine che esiste tra la realtà e ciò che la simula. II rapporto con il manufatto viene quindi filtrato da schemi precostituiti, basati su linguaggi interattivi ed immersivi, che ne condizionano la conoscenza e la traspongono in ambienti virtuali, allontanando, di fatto, il fruitore dal manufatto reale.

Ciononostante, il ricorso a tecniche e tecnologie proprie dell'Extended-Reality $(X R)$, se relazionato ad obiettivi di ampliamento e miglioramento della fruizione in sito, diventa un valido supporto per riconnettere attraverso modalità alternative il patrimonio costruito, piuttosto che sostituirsi ad esso. Particolare attenzione va posta nella strutturazione della scena virtuale e dell'esperienza di fruizione - coerenza delle informazioni, tipologia di contenuto informativo, modalità di fruizione ecc. - affinché il risultato ottenuto sia quello atteso. In tal senso, infatti, progetti di comunicazione e divulgazione possono divenire il mezzo per incuriosire e destare interesse nel fruitore virtuale, spingendolo a recarsi in sito e godere dell'esperienza diretta.

In tale ambito, si colloca la ricerca - ancora in corso - condotta come sperimentazione durante il Dottorato di Ricerca in Architettura presso l'Università di Napoli Federico II e che nel presente contributo vede l'esplicitazione dei primi risultati ottenuti. Le diverse tematiche indagate sono affrontate attraverso il caso studio dell'Hospital Simón Ruiz (fig. I) di Medina del Campo (Valladolid, Spagna), un edificio costruito tra la fine del XVI secolo e l'inizio del XVII secolo su richiesta di Simón Ruiz, un commerciante-banchiere molto noto in tutto il regno spagnolo, le cui attività sono intrecciate con diversi paesi europei tra cui l'Italia [Pulido Serrano 2017].

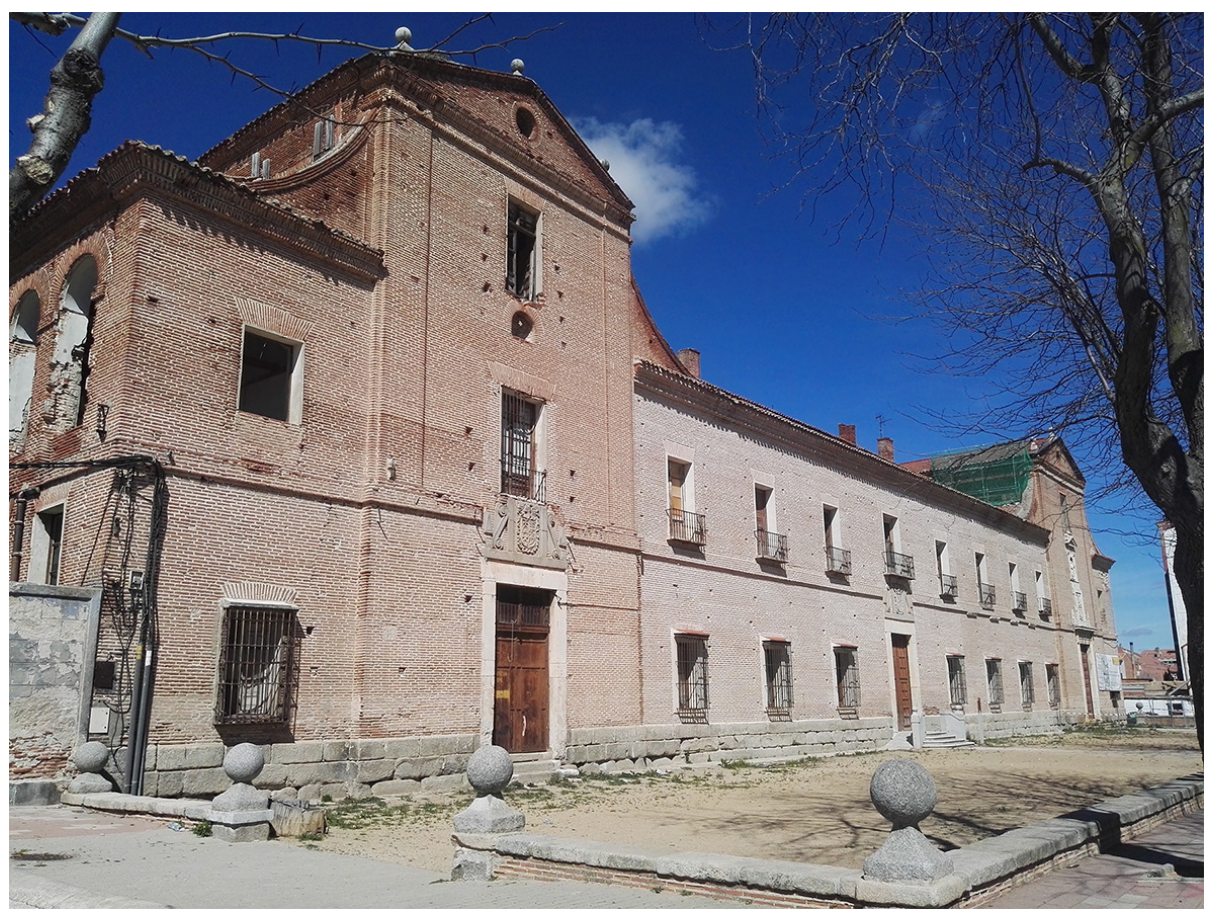




\section{Modelli interattivi ed informatizzati del patrimonio costruito}

Tra le diverse possibilità introdotte dagli sviluppi metodologici degli ultimi decenni, il ricorso a modelli Heritage-BIM per la documentazione dell'esistente è un tema di grande interesse nella comunità scientifica di settore. Sono ampiamente note le difficoltà dell'applicazione della metodologia BIM al patrimonio costruito, per la strutturazione di smart-objects non previsti dalle attuali piattaforme software, ma necessari per la caratterizzazione dei manufatti storici. Ma sono altrettanto evidenti le potenzialità nella conformazione di banche dati digitali, dove raccogliere, sintetizzare e relazionare la mole di informazioni eterogenee che lo connotano. II tutto viene reso più agevole associando il modello H-BIM alle tecniche di fruizione $\mathrm{XR}$ e costruendo un progetto di comunicazione che, di fatto, assume la doppia valenza conoscitiva e divulgativa, non solo per gli specialisti del settore AEC, ma anche per una più ampia gamma di utenti.

Sebbene l'applicazione dell'XR al patrimonio costruito non sia un tema nuovo, è ancora molto investigato [Empler et al. 2019; Mann et al. 20 I8]; ad oggi, infatti, numerosi studi e ricerche si interrogano sull'individuazione di metodologie idonee per gestire le possibili connessioni tra il modello BIM e le attuali forme di fruizione (AR, MR e VR), [Davidson et al. 2019].

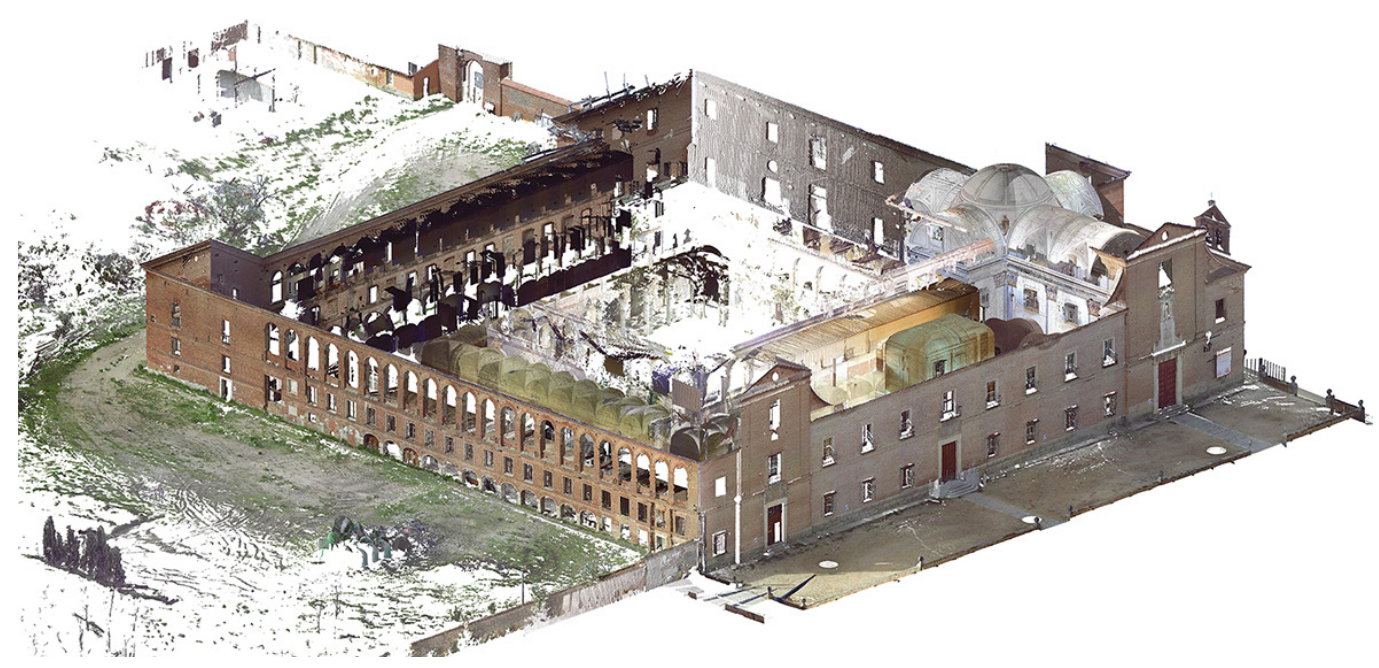

Molteplici sono i fattori che entrano in gioco. Ad esempio, la necessità di garantire che le innumerevoli informazioni che corredano il modello geometrico non siano perse nel passaggio all'XR. A tal proposito, va precisato che le piattaforme BIM, nel loro sviluppo, hanno implementato tools e plugin per visualizzazioni direttamente in $A R$ e VR, o per esportazioni in software dedicati - i visualizzatori -, consentendo la fruizione, con modalità alternative, del modello e delle informazioni ad esso associate [di Luggo et al. 20 19]. Ma non sempre il risultato che offrono è ritenuto adatto al perseguimento degli obiettivi, poiché le semplificazioni grafiche che introducono per rendere fluida la visione del modello, ne influenzano, di fatto, la resa realistica; a ciò si aggiunge l'interattività della scena che non sempre è possibile garantire. Per cui, si tende a ricorrere a software propri del gaming engine che, oltre alle rese altamente fotorealistiche delle texture associate agli oggetti tridimensionali, consentono di progettare la fruizione della scena attraverso i comuni linguaggi di programmazione $(\mathrm{C}++$, C\#, Payton etc.). 
Altro aspetto da tenere in considerazione riguarda la realizzazione, dal punto di vista geometrico e formale [Brumana et al. 20 I7; Fai, Rafeiro 20 I4], degli smart-objects che caratterizzano il modello H-BIM: tema strettamente connesso alla sfera della rappresentazione ed oggetto di numerosi dibattiti, ancora irrisolti, incentrati sulle modalità e sul grado di semplificazione con cui trattare gli elementi del Patrimonio Costruito, spesso connotati da elevata complessità. Tema che diventa ancor più rilevante se legato ad obiettivi di fruizione virtuale in cui le operazioni di rendering in real-time, alla base delle tecnologie $X R$, impongono di non appesantire la gestione grafica del progetto affinché non ne risenta la fluidità della scena e del suo sviluppo. Per cui è necessario, già in fase di modellazione H-BIM individuare il giusto grado di semplificazione, che sia coerente con la gestione dell' $X R$ e che, al contempo, risulti idoneo alla comprensione dei contenuti.
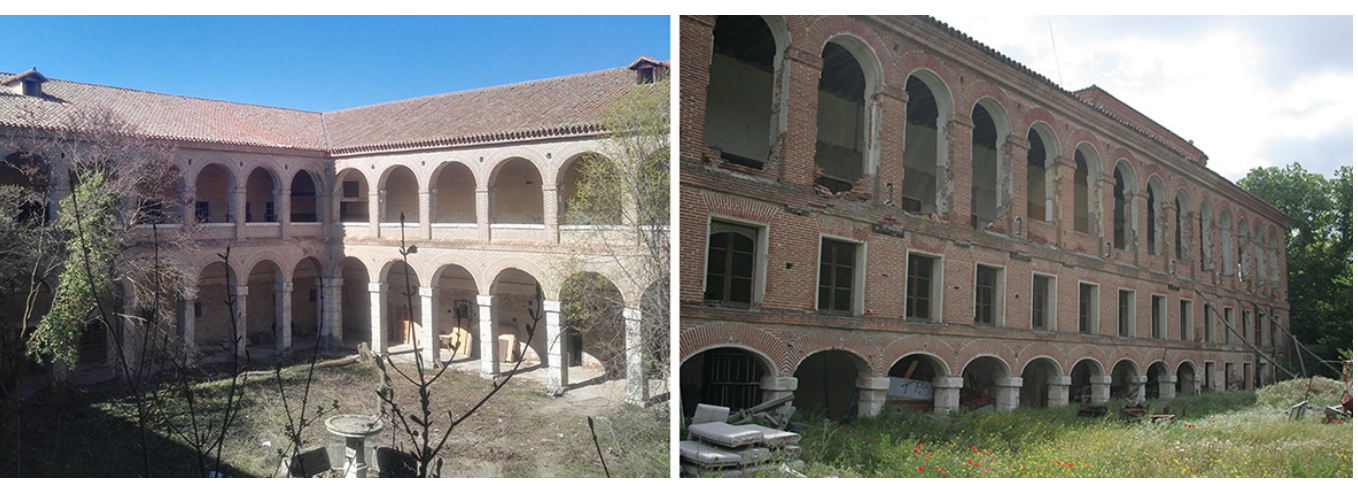

\section{La nuvola di punti range-based}

Lo stato di degrado in cui versa l'intero complesso, dovuto all'abbandono nel tempo ma sviluppatosi repentinamente in pochi decenni, ha comportato un'attenta progettazione del rilievo a causa dell'inaccessibilità di alcuni spazi. Al contempo, però, ha messo in evidenza, ancora una volta, come in situazioni critiche come quella presentata dal Simón Ruiz, il ricorso a strumentazioni reality-based agevola l'acquisizione delle informazioni, producendo in tempi brevi un'elevata quantità di dati, accurati dal punto di vista metrico e geometrico.

Nello specifico, sono state condotte due campagne di acquisizione range-based (aprile 20 I 8 e luglio 20I8), con strumentazione laser - Faro Focus 3D s 120 e ×330 -, volte alla definizione morfologica del complesso, oltre che materico-colorimetrica data dall'acquisizione contestuale del dato RGB. Le fasi di acquisizione ed elaborazione della nuvola di punti sono state gestite separatamente, definendo di volta in volta i parametri delle singole scan positions in funzione dell'ottimizzazione dei tempi, della diminuzione della ridondanza e della gestione nelle fasi successive. L'allineamento delle scan positions si è ottenuto mediante targets apposti nella scena, mentre l'integrazione dei dati delle due acquisizioni è stata operata attraverso l'individuazione di targets naturali all'interno del software proprietario Faro SCENE associato alla strumentazione laser. La nuvola di punti complessiva (fig. 2) è stata oggetto di fasi di post-processing volte alla riduzione del rumore e alla segmentazione in blocchi al fine di agevolare la gestione del dato nelle fasi successive di interpretazione e restituzione del rilievo.

\section{Le regole compositive del Simón Ruiz}

Ritmo e modularità regolano lo schema compositivo dell'Hospital Simón Ruiz. Dall'analisi e dall'interpretazione degli ortofotopiani - di pianta, sezione ed alzato - estratti dalla nuvola di punti, sono stati individuati i rapporti geometrici e le regole costitutive sottese alle forme, confermando in parte le ipotesi esplicitate da L. Navarro García nel testo del 1998 [Navarro García 1998]. 
In pianta, ad esempio, si è riscontrato che la figura geometrica del quadrato regola la composizione del complesso e della corte, mentre la chiesa, collocata nell'angolo inferiore destro, presenta rapporti proporzionali di 2 a 3 nello sviluppo longitudinale e trasversale. La mancanza di assialità della corte e le dimensioni della chiesa, si riflettono nella configurazione dei bracci del complesso, che risultano a due a due corrispondenti.

Ma è nei fronti, caratterizzati da registri linguistici differenti, che è chiaramente leggibile la volontà di rifarsi ad uno schema preciso, espresso dal ritmo costante nell'alternanza delle parti piene e di quelle vuote. Le ampie aperture dei fronti della corte, descritti da un doppio ordine di arcate allineate lungo l'asse verticale, e di quelli verso il giardino, dove, invece, alle arcate viene interposto un filare di finestre, consentono le connessioni con gli spazi esterni, fondamentali per la degenza degli ammalati (fig. 3). Mentre aperture di dimensioni inferiori e prevalenza di parti piene, caratterizzano il fronte principale e quello su strada, filtrando, di fatto, il rapporto con la città. Sfuggono alla regola alcune eccezioni, che, tuttavia, possono essere considerate trascurabili nella lettura e nell'interpretazione d'insieme del complesso.

\section{La costruzione del modello H-BIM}

Gli schemi emersi dagli studi compositivo-proporzionali sono, quindi, divenuti l'ossatura del modello H-BIM, relazionando in tal modo l'Hospital Simón Ruiz, nella sua consistenza reale espressa dalla nuvola di punti, con le regole costitutive che lo connotano (figg. 4, 5). In tal senso, nella costruzione del modello H-BIM si è scelto di utilizzare griglie e piani di riferimento, messi a disposizione dalla piattaforma Autodesk Revit, per riproporre e gestire il ritmo pieni/vuoti presente sui fronti del complesso.

Ad esempio, per i fronti sul giardino sono stati modellati gli smart-objects (famiglie caricabili nella logica Revit) corrispondenti alle arcate inferiori, alle finestre e alle arcate superiori, mantenendo centrali gli assi di riferimento presenti di default nel template utilizzato (finestra metrica e porta metrica) (fig. 6). Nella costruzione delle diverse famiglie, si è scelto di operare attraverso semplificazioni delle forme che, se da un lato hanno agevolato le operazioni di modellazione, dall'altro hanno permesso di ottenere, egualmente, un modello coerente e rispondente al reale dal punto di vista della resa visiva.

In ambiente di progetto, al riferimento digitale è stato vincolato l'asse verticale delle famiglie in modo da poterne gestire contestualmente la posizione. II raggruppamento delle diverse aperture e la riproduzione in serie - con definizione della lunghezza della serie e del numero di elementi - ha permesso di costruire il fronte in tempi brevi e mantenere costante la distanza tra i diversi elementi (fig. 7). Analogamente si è proceduto anche per gli altri fronti e, più in generale, per la costruzione del modello.

II confronto con la nuvola di punti, in software specifici, ha permesso di stabilire la divergenza del modello rispetto alla conformazione reale dell'Hospital Simón Ruiz (fig. 8). Dalla lettura dei risultati, nonostante l'elevata aderenza emersa, si è, quindi, individuato un duplice livello di rilevanza in base ai discostamenti riscontrati nei singoli elementi e nella loro disposizione, ritenendo il primo meno influente nella definizione della coerenza nella rappresentazione digitale del manufatto.

\section{Sviluppi futuri della ricerca e conclusioni}

Le riflessioni e gli approcci metodologici esposti nel presente contributo, in linea con l'attuale dibattito scientifico di settore, rappresentano l'inizio di una ricerca ancora in corso, volta alla costruzione di scenari virtuali del patrimonio costruito. Nella traduzione della nuvola di punti in fruizioni $X R$ - con particolare riferimento alle tecniche di virtual reality - si è individuato nel modello Heritage-BIM il supporto 3D idoneo a rispondere agli obiettivi prefissati, legati alla costruzione di modelli interattivi ed informatizzati (fig. 9).

La tematica principale su cui la ricerca si focalizza, quindi, è rappresentata proprio dalle modalità di connessione tra diverse forme di rappresentazione (nuvola di punti, modello 
Fig. 4. Lettura geometrica e dei rapporti compositivo-proporzionali nello sviluppo planimetrico dell'Hospital Simón Ruiz.

Fig. 5. Lettura geometrica e dei rapporti com-

positivo-proporzionali

nei fronti a partire da ortofotopiani estratti
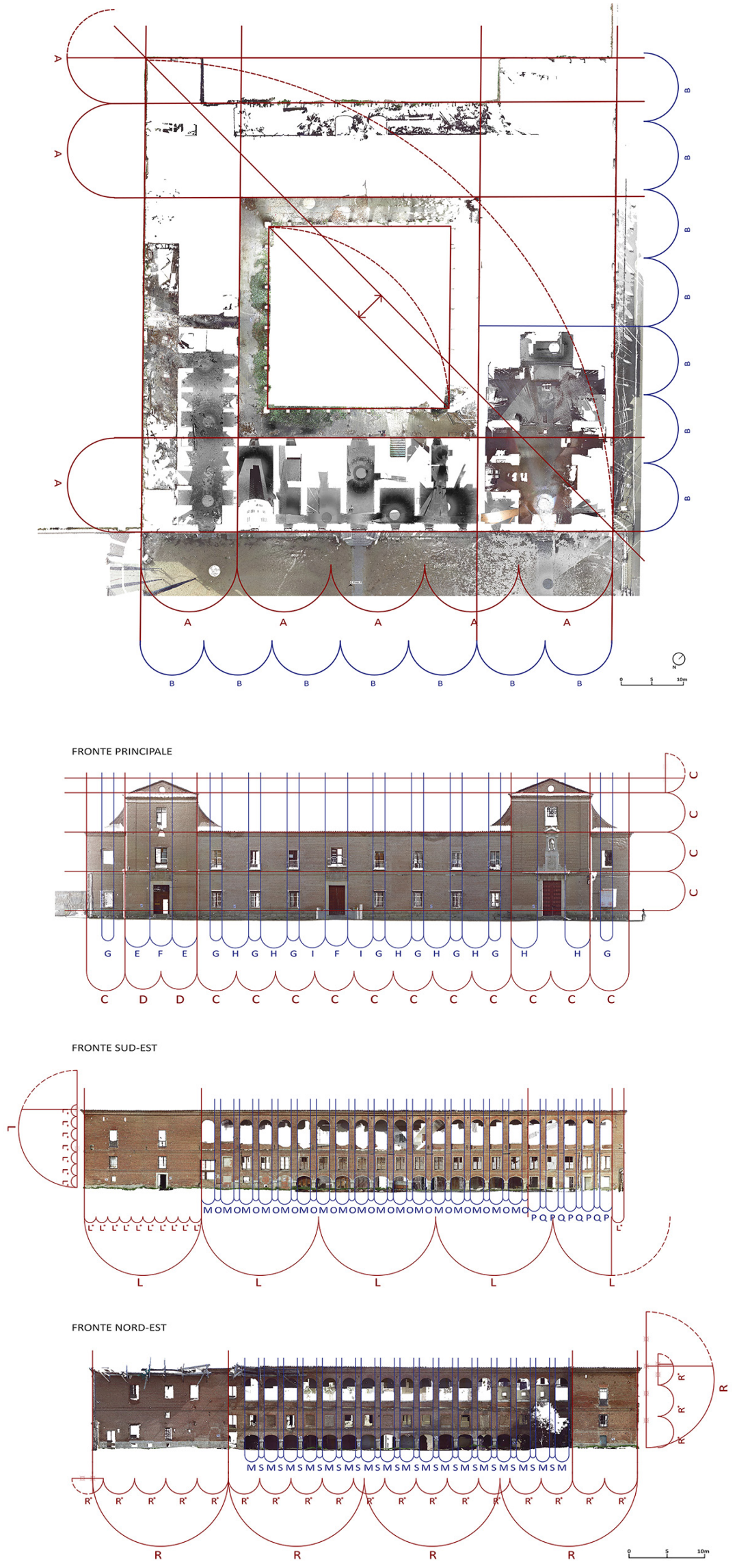
Fig. 6. Allineamento, in ambiente di progetto, delle famiglie di porte e finestre rispetto all'asse di riferimento verticale: vista tridimensionale e di prospetto

Fig. 7. Processo di modellazione $\mathrm{H}$-BIM del fronte Sud-Est.
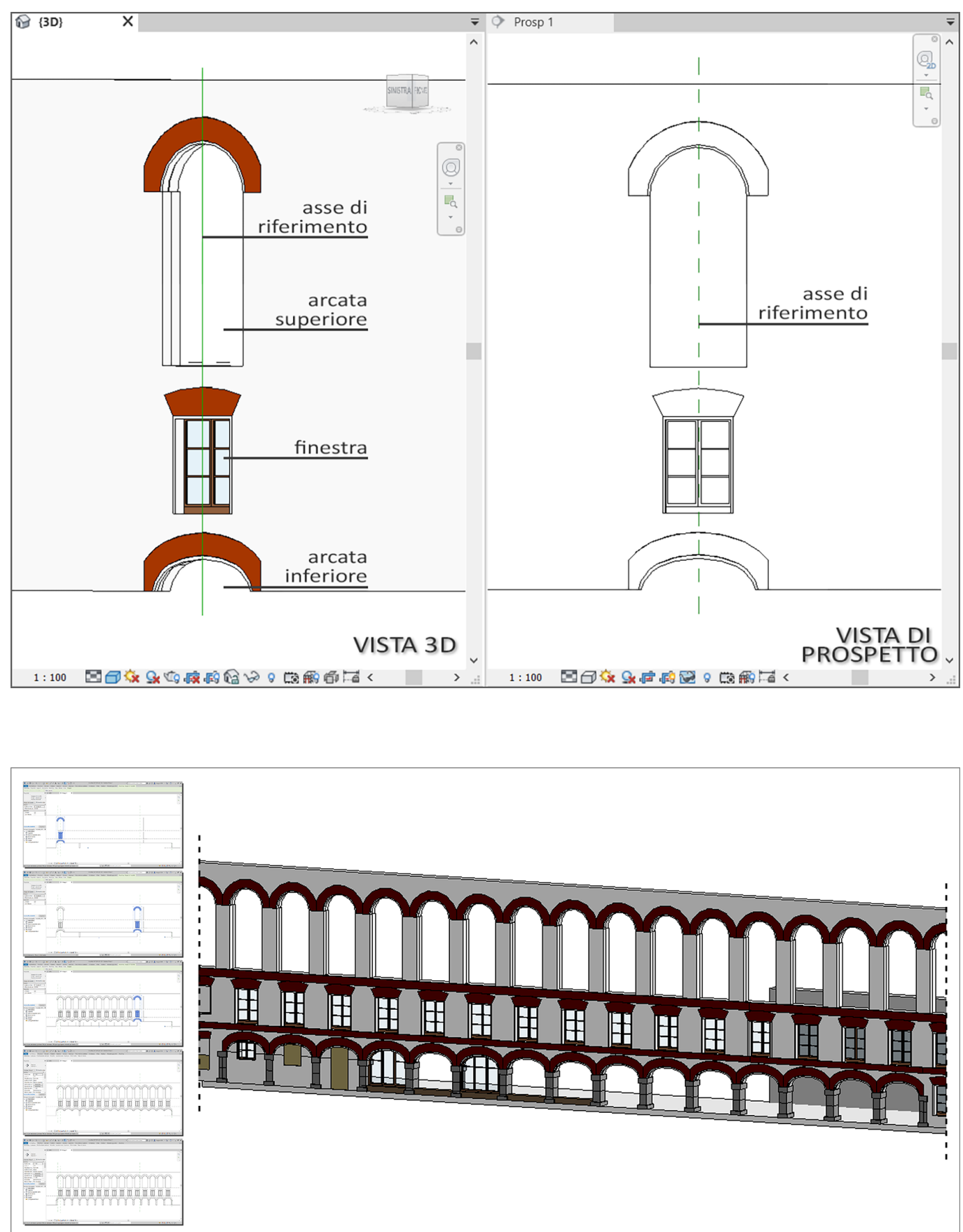


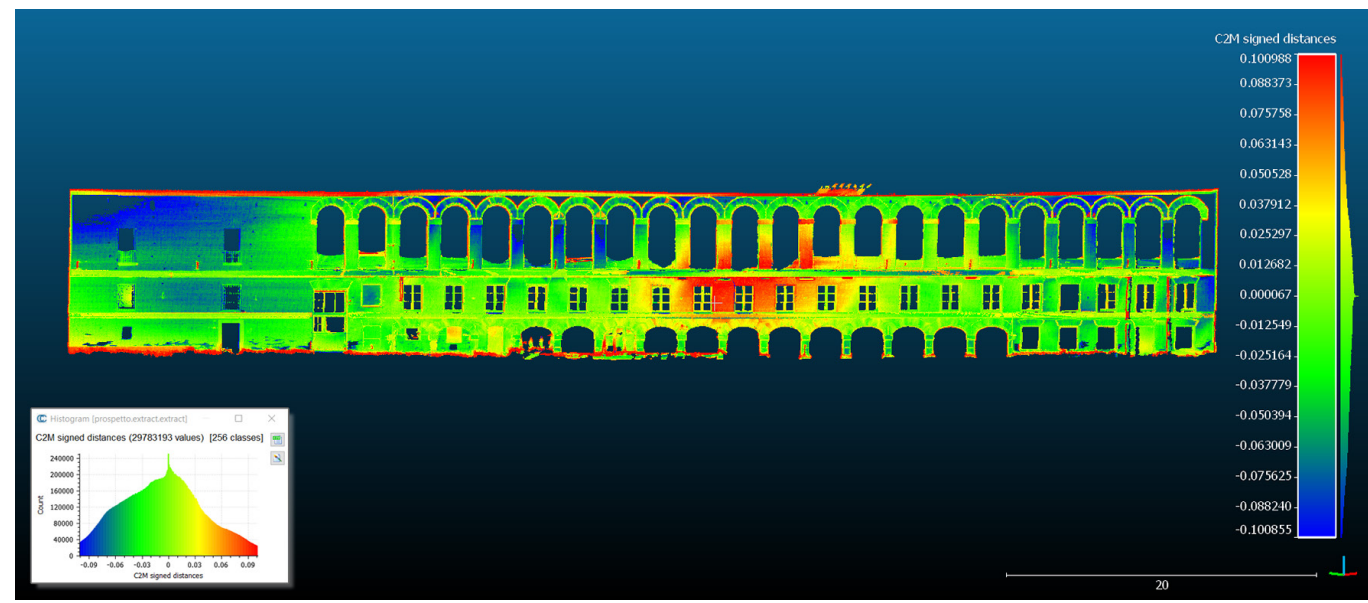

informativo e fruizione virtuale). Tale connessione, seppur ipotizzata come un unico processo, si suddivide in due fasi, apparentemente distinte e separate. Una prima, destinata alla restituzione del rilievo reality-based attraverso la modellazione $\mathrm{H}-\mathrm{BIM}$, gestita con l'individuazione delle regole compositive del manufatto. La seconda, invece, che relaziona il modello informativo con le più attuali tecniche di fruizione virtuale, individuando quella che meglio si presta a gestire i diversi livelli di lettura che il modello consente. Gli sviluppi futuri della ricerca sono proprio incentrati su questa fase, al fine di estendere la conoscenza del manufatto, esemplificato dall'Hospital Simón Ruiz, fino a rintracciare le sue regole costitutive senza, però, perdere tutte le informazioni ad esso associate. In tal ottica, è nel modello H-BIM che si individua il legame tra la nuvola di punti e la fruizione virtuale, rendendo il tutto un unico processo.

Fig. 9. Workflow: dal reale al reale esteso per la costruzione di modell interattivi ed informatizzati.
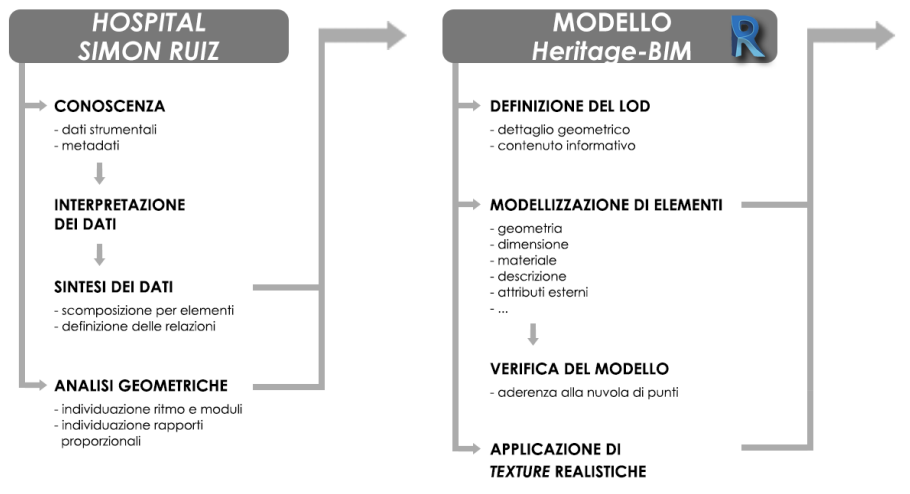

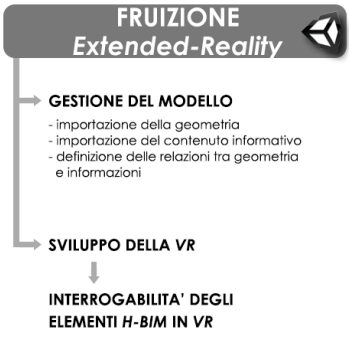

work in progress..

\section{Riferimenti bibliografici}

Brumana Raffaella, Della Torre Stefano, Oreni Daniela, Previtali Mattia, Cantini Lorenzo, Barazzetti, Luigi, Franchi Alberto, Banfi Fabrizio (2017). HBIM challenge among the paradigm of complexity, tools and preservation: The Basilica di Collemaggio 8 years after the earthquake (L'Aquila). In The International Archives of the Photogrammetry, Remote Sensing and Spatial Information Sciences, XLII-2/W5, 2017, pp. 97-104.

Davidson Jordan, Fowler John, Pantazis Charalampos, Sannino Massimo, Walker Jordan, Sheikhkhoshkar Moslem, Rahimian Farzad Pour (2019). Integration of VR with BIM to facilitate real-time creation of bill of quantities during the design phase: a proof of concept study. In Frontiers of Engineering Management, 20 I9, pp. I-8. 
Di Luggo Antonella, Palomba Daniela, Pulcrano Margherita, Scandurra Simona (2019). Theoretical and Methodological Implications in the Information Modelling of Architectural Heritage. In Bolognesi Cecilia Maria, Santagati Cettina (eds.). Impact of Industry 4.0 on Architecture and Cultural Heritage. United States of America: IGl Global editore, pp. 20-48.

Empler Tommaso, Caldarone Adriana, Fusinetti Alexandra (2019). Leonardo da Vinci: divulgazione delle sue opere attraverso i Serious Game. In Paolo Belardi (a cura di). Riflessioni. L'arte del disegno/il disegno dell'arte. Atti del $41^{\circ}$ Convegno Internazionale dei Docenti delle Discipline della Rappresentazione. Perugia 19-2 I Settembre 20 I 9. Roma: Gangemi editore, pp. I553- I562.

Fai Stephen, Rafeiro Jesse (20I4). Establishing an appropriate Level of Detail (LOD) for a Building Information Model (BIM)West Block, Parliament Hill, Ottawa, Canada. In ISPRS Annals of the Photogrammetry, Remote Sensing and Spatial Information Sciences, II-5, 2014, pp. I23-130.

Mann Steve, Furness Tom, Yuan Yu, lorio Jay, Wang Zixin (20।8). All Reality:Virtual, Augmented, Mixed (X), Mediated (X,Y), and Multimediated Reality. In ArXiv, Aprile, 8, 2018.

Navarro García Luis (1998). El Hospital General de Simón Ruiz en Medina del Campo: Fábrica e Idea. Salamanca: Junta de Castilla y Leon.

Pulido Serrano Juan Ignacio (2017). Más que negocios: Simón Ruiz, un banquero español del siglo XVI entre las penínsulas ibérica e italiana. S.L.: Iberoamericana Editorial Vervuert.

\section{Autore}

Margherita Pulcrano, Università degli Studi di Napoli “Federico II”, margherita.pulcrano@unina.it

Per citare questo capitolo: Pulcrano Margherita (2020). Modelli digitali interconnessi per ampliare la conoscenza e migliorare la fruizione del patrimonio costruito/Digital models interconnected to expand knowledge and improve the use of cultural heritage. In Arena A...Arena M., Brandolino R.G., Colistra D. Ginex G. Mediati D. Nucifora S., Raffa P. (a cura di). Connettere. Un disegno per annodare e tessere. Atti del $42^{\circ}$ Convegno Internazionale dei Docenti delle Discipline della Rappresentazione/Connecting. Drawing for weaving relationships. Proceedings of the 42 th International Conference of Representation Disciplines Teachers. Milano: FrancoAngeli, pp. 2604-2621. 


\section{Digital Models Interconnected to Expand Knowledge and Improve the Use of Cultural Heritage}

Margherita Pulcrano

\section{Abstract}

The contribution reports the first results of a research in progress that intends to investigate the connections between different ways of representing the cultural heritage: the point cloud (obtained through range-based technologies), the information model (deriving from the application of the BIM methodology) and virtual fruition (with particular interest in virtual reality). Case study on which to test the application and verify the hypothesized process, intended as a unique and continuous workflow, is the Simón Ruiz Hospital in Medina del Campo (Valladolid, Spagna), counted among the oldest buildings in the city.

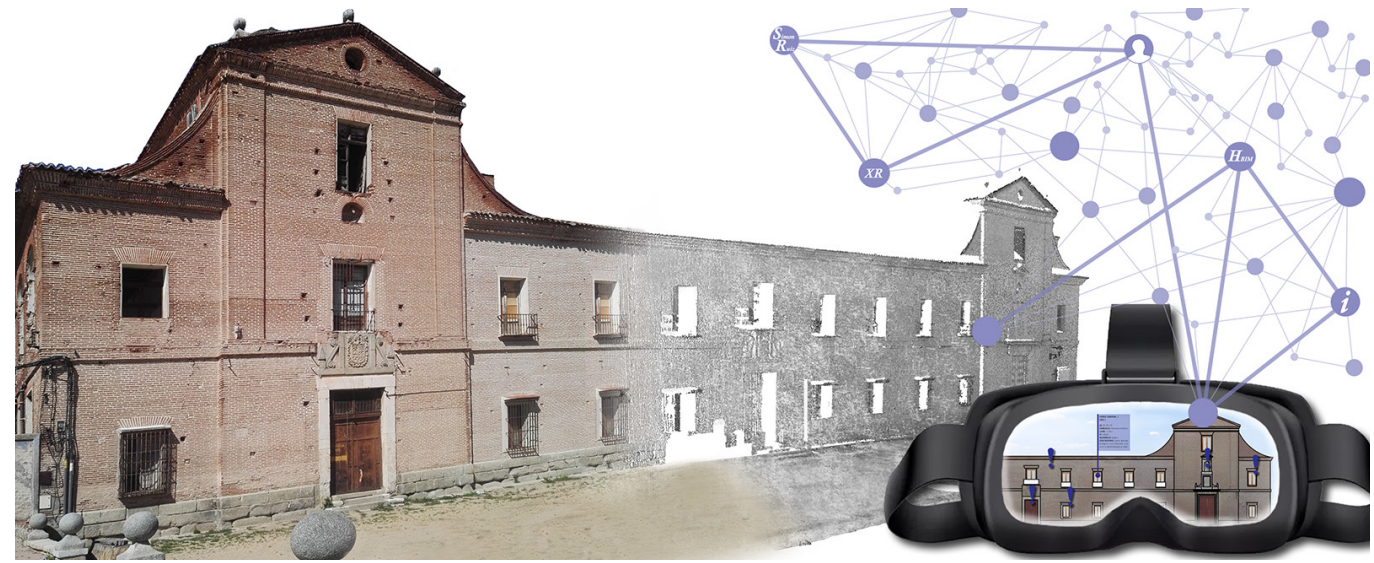




\section{Introduction}

Today, in the era of Industry 4.0 and loT (Internet of Things), the risk of losing contact with the reality around us is very high. From personal relationships mediated by social media to the purchase of goods and services, sometimes primary, through app or dedicated websites, there is no aspect disconnected from the use of digital technologies.

Even the field of cultural heritage is not immune to it. Always more often, in fact, hyper-realistic 3D models emulate the constructed -or prefigured- reality with meticulous reconstructions of the aspects and characteristics that connote it. Through specific vision tools, these models provide multi-sensory experiences that tend to exceed the subtle border that exists between reality and what simulates it. The relationship with the artefact is then filtered by pre-established schemes, based on interactive and immersive languages, which condition its knowledge and transpose it into virtual environments, turning away the user from the real artefact.

Nevertheless, the use of Extended-Reality $(X R)$ techniques and technologies, if related to the objectives of expanding and improving the use on site, becomes a valid support for re-connecting the built heritage through alternative methods, rather than replacing it. Particular attention must be paid to the structuring of the virtual scene and the experience of use -consistency of information, type of information content, method of fruition etc.- so that the result obtained is the expected one. In this sense, in fact, communication and dissemination projects can become the means to intrigue and arouse interest in the virtual user, pushing him to go to the site and enjoy direct experience.

In this field, the search is placed -still in progress-carried out as an experiment during the $\mathrm{PhD}$ in Architecture at the University of Naples Federico II and which in this contribution sees the explanation of the first results obtained. The different topics related to the research activities are addressed through the case study of the Simón Ruiz Hospital (fig. I) in Medina del Campo (Valladolid, Spain), a building built between the end of the I6th century and the beginning of the 17th century at the request of Simón Ruiz, a well-known merchant-banker throughout the Spanish kingdom, whose activities are related with several European countries including Italy [Pulido Serrano 20 I7].

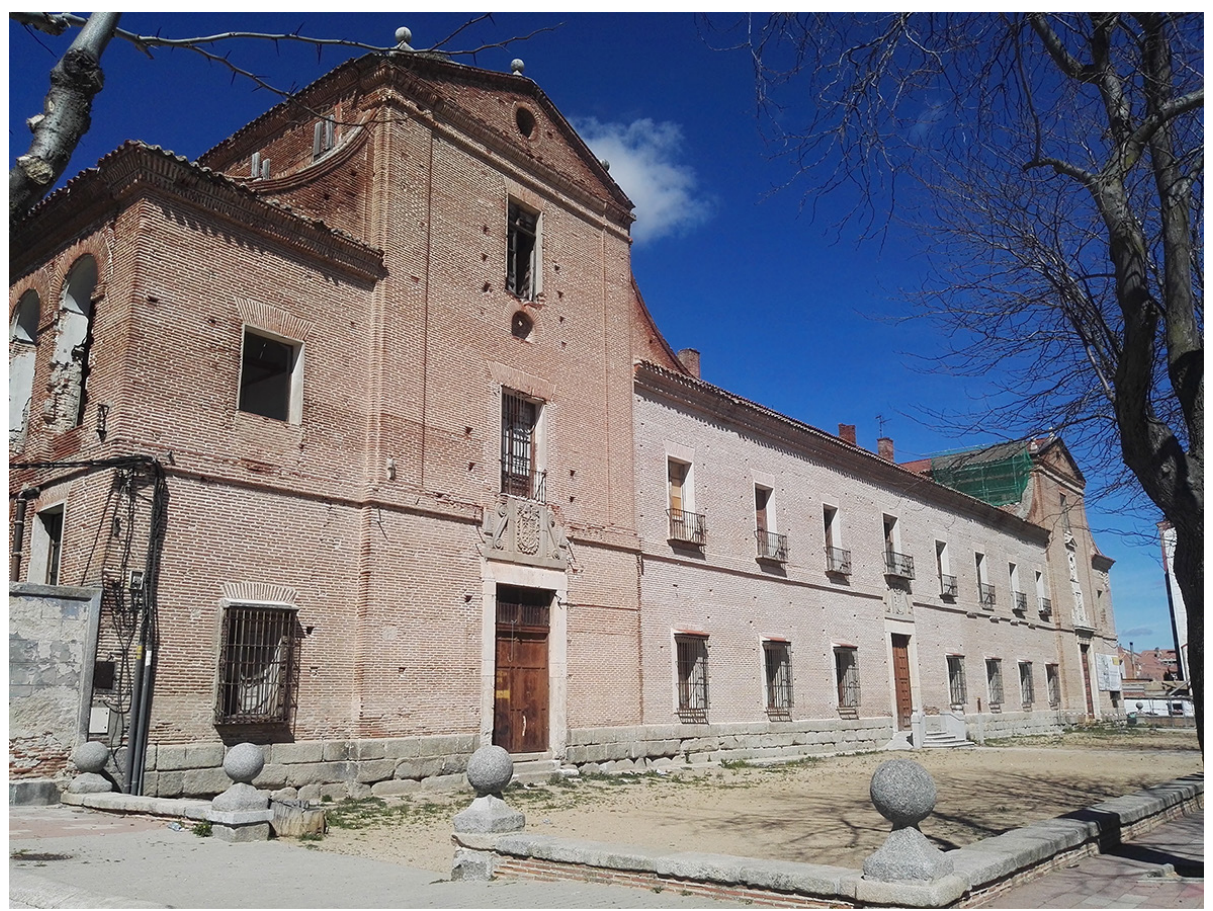




\section{Interactive and informative models of the built heritage}

Among the various possibilities introduced by the methodological developments of the last decades, the use of Heritage-BIM models, for the documentation of the existing is a topic of great interest in the scientific community of the sector.The difficulties of applying the BIM methodology to the built heritage are widely known, for the structuring of smart objects not foreseen by the current software platforms, but necessary for the characterization of the historical artefacts. But the potential in the conformation of digital databases is equally evident, where it is possible to collect, synthesize and relate the amount of heterogeneous information that connotes it. All this is made easier by associating the $\mathrm{H}$-BIM model with the $\mathrm{XR}$ fruition techniques and by building a communication project that takes on the double cognitive and popular value, not only for specialists in the AEC sector, but also for a wider range of users.

Although the application of $X R$ to built heritage is not a new topic, it is still highly investigated [Empler et al. 20 19; Mann et al. 20 I8], nowadays, in fact, numerous studies and research tests the appropriate methodologies to manage the possible connections between the BIM model and the current forms of fruition (AR, MR and VR) [Davidson et al. 2019].

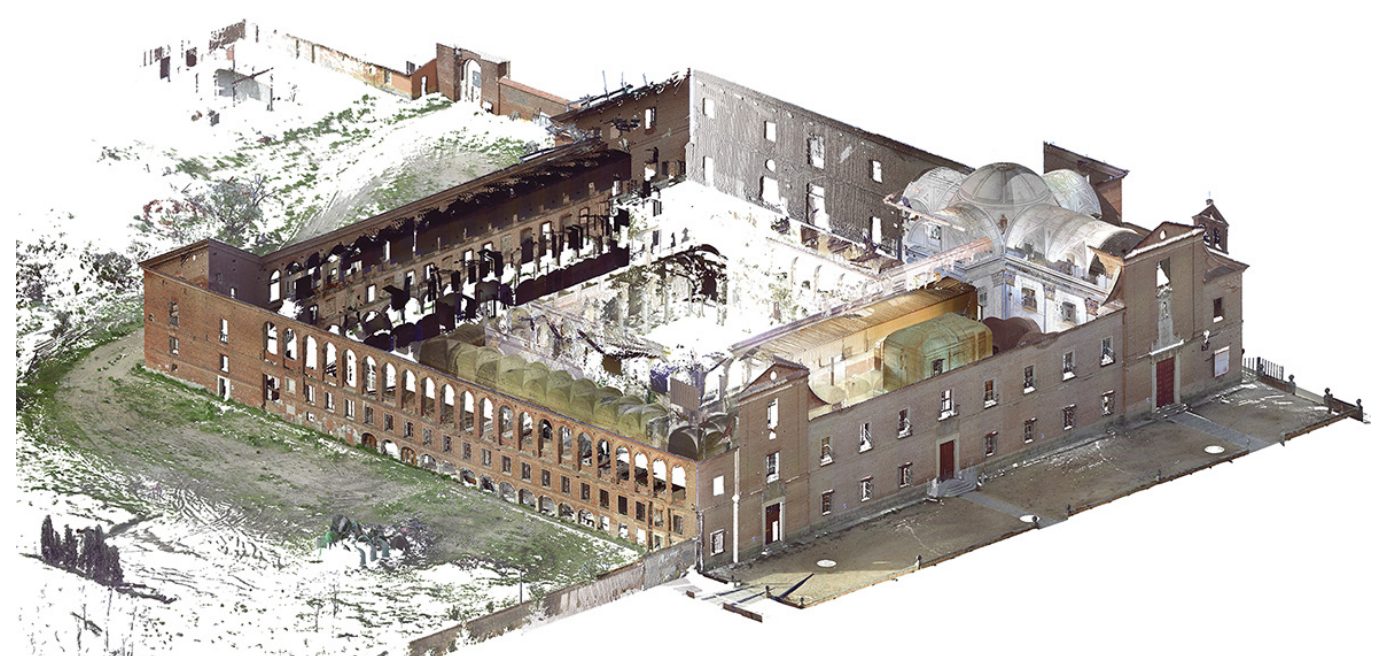

There are many factors that come into play. For example, the need to ensure that the countless information that accompanies the geometric model is not lost in the transition to $X R$. About that, it should be noted that the BIM platforms, in their development, have implemented tools and plugins for visualization directly in AR and VR, or for exports in dedicated software -the so-called viewers- allowing the fruition, with alternative methods, of the model and the information associated with it [di Luggo et al. 2019]. But the result they offer is not always considered suitable for the objectives, because the graphic simplifications that they introduce to make the fluid vision of the model, influence its realistic rendering; added to this is the interactivity of the scene that cannot always be guaranteed. Therefore, there is a tendency to use specific software to the gaming engine which, enable to obtain highly photorealistic visions of 3D objects' texture and to plan the fruition of the scene through common programming languages ( $\mathrm{C}++, \mathrm{C} \#$, Payton etc.). 
Another aspect to be taken into consideration concerns the creation, from a geometric and formal point of view [Brumana et al. 20 I7; Fai, Rafeiro 20 I4], of the smart-objects that characterize the H-BIM model: a theme strictly connected to the sphere of representation and the subject of numerous debates, still unsolved, focused on the methods and on the degree of simplification of the built heritage elements, often characterized by high complexity. Topic that becomes even more relevant if linked to virtual fruition objectives in which the real-time rendering operations, at the basis of the $X R$ technologies, require that the graphic management of the project not be weighed down so that the fluidity of the scene and its development. So it is necessary, already in the H-BIM modeling phase, to identify the right degree of simplification, which is coherent with the management of the $X R$ and which, at the same time, is suitable for understanding the contents.
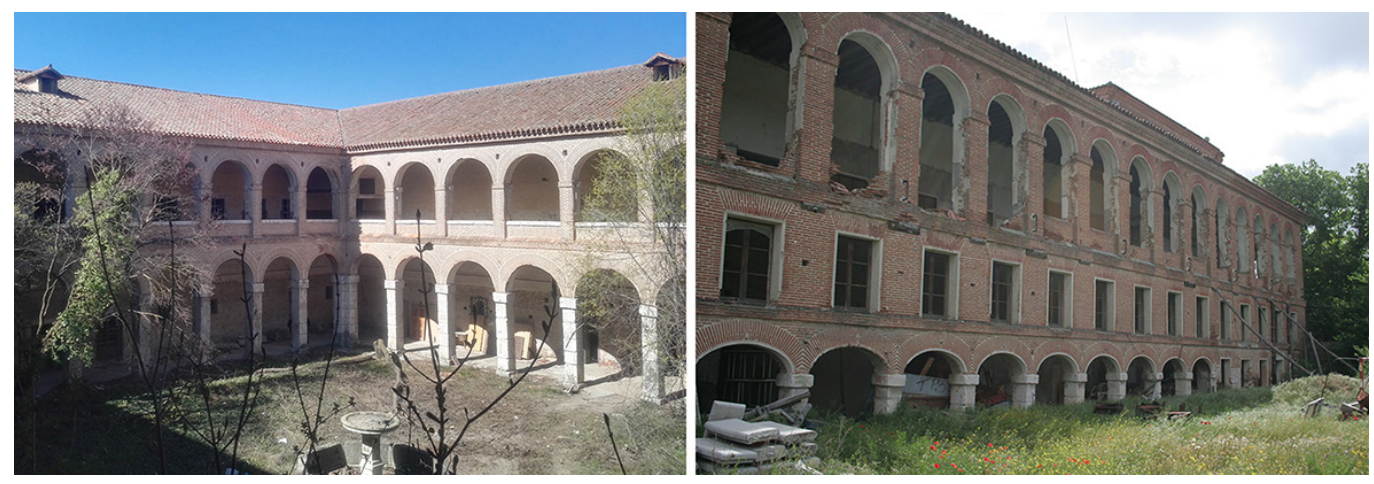

\section{The range-based point cloud}

The decay state of the complex, caused to abandonment over time but which developed rapidly in a few decades, imposed careful planning of the survey due to the inaccessibility of some spaces. At the same time, however, it highlighted as in critical situations, such as Simón Ruiz, the use of reality-based technologies simplify the acquisition of information, producing in a short time a high amount of data, metric and geometric accurate.

Specifically, two range-based acquisition were conducted (April 2018 and July 20I8), with laser instrumentation -Faro Focus 3D s/20 and ×330-, aimed at the morphological definition of the complex, as well as material-colorimetric given by the contextual acquisition RGB data. The acquisitions and processing phases were managed separately, defining the parameters of the individual scan positions from time to time according to the optimization, the reduction of redundancy and the management of post-operations. The alignment of the scan positions was achieved by means of targets affixed to the scene, while the integration of the two acquisitions data was carried out through the identification of natural targets within the Faro SCENE software. The total point cloud (fig. 2) has been subject to post-processing phases aimed at reducing noise and segmenting into blocks in order to facilitate data management in the subsequent phases of survey interpretation and restitution.

\section{The compositional rules of Simón Ruiz}

Rhythm and modularity regulate the compositional scheme of the Simón Ruiz Hospital. From the orthophotopians analysis and interpretation -plan, section and elevation- extracted from the point cloud, the geometric relationships and the constitutive rules underlying the forms were identified, partially confirming the hypotheses explained by L. Navarro García in the text of the 1998 [Navarro García 1998]. 
In plan, for example, it has been found that the square form regulates the composition of the complex and the court, while the church, located in the lower right corner, has proportions of 2 to 3 in the longitudinal and transversal development. The not axiality of the court and the size of the church are reflected in the complex's arms configuration, which are two by two corresponding.

But it is on the fronts, characterized by different linguistic registers, that the desire to refer to a precise pattern, expressed by the constant rhythm in the alternation of full and empty parts, is clearly legible. The wide hole on the court fronts, described by a double order of arches aligned along the vertical axis, and those towards the garden, where, instead, a line of windows is placed between the arches, allow connections with the external spaces, fundamental for the hospitalization of the sick (fig. 3). While smaller openings and prevalence of full parts characterize the main front and the street front, effectively filtering the relationship with the city. Some exceptions escape the rule, which, however, can be negligible in the reading and overall interpretation of the complex.

\section{The construction of the H-BIM model}

The patterns of the compositional-proportional studies have become the backbone of the H-BIM model, relating the Simón Ruiz Hospital in its real consistency expressed by the point cloud, with the constitutive rules that characterize it (figs. 4, 5). In this sense, in the construction of the $\mathrm{H}$-BIM model it was decided to use reference grids and planes, made available by the Autodesk Revit platform, to re-propose and manage the full/empty rhythm present on the fronts of the complex.

For example, for the fronts on the garden the smart-objects (families loadable in Revit) have been modeled corresponding to the lower arches, the windows and the upper arches, keeping the reference axes central present by default in the template used (metric window and metric door), (fig. 6). In the construction of the different families, we have chosen to operate through forms simplifications, which, if on the one hand they have facilitated the modeling operations, on the other hand have made it possible to obtain, equally, a coherent and responsive model from the visual rendering point of view.

In the project environment, the vertical axis of the families has been linked to the digital reference so that to simultaneously manage their position. The grouping of the different families and the reproduction in series - with definition of the series length and the number of elements- made it possible to build the front in a short time and keep the distance between the different elements constant (fig. 7). Similarly, we proceeded for the other fronts and, more generally, for the model construction.

The comparison with the point cloud, in specific software, allowed to establish the divergence of the model with the actual shape of the Simón Ruiz Hospital (fig. 8). From reading the results, although the high adherence that emerged, a double level of relevance was identified based on the differences found in the individual elements and in their position, considering the first less influential in defining consistency in the digital representation of the artefact.

\section{Future research developments and conclusions}

The issues and methodological approaches presented in this paper, in line with the current scientific questions in the sector, represent the beginning of an ongoing research, aimed at building virtual scenarios of the cultural heritage. In the translation of the point cloud into XR fruition -with particular reference to Virtual Reality techniques- the Heritage-BIM model has been identified as the 3D support suitable for responding to the set objectives, connected to the construction of interactive and informative models (fig. 9).

The main topic on which the research focuses, therefore, is represented by the methods of connection of different representation forms (point cloud, information model and virtual fruition). This connection, although hypothesized as a single process, is divided into two 
Fig. 4. Geometrical and proportional relationships reading in the Simon. Ruiz Hospital planimetric development.

Fig. 5. Geometrical and proportional relationships reading in the fronts based on orthophotopians extracted from the point cloud.
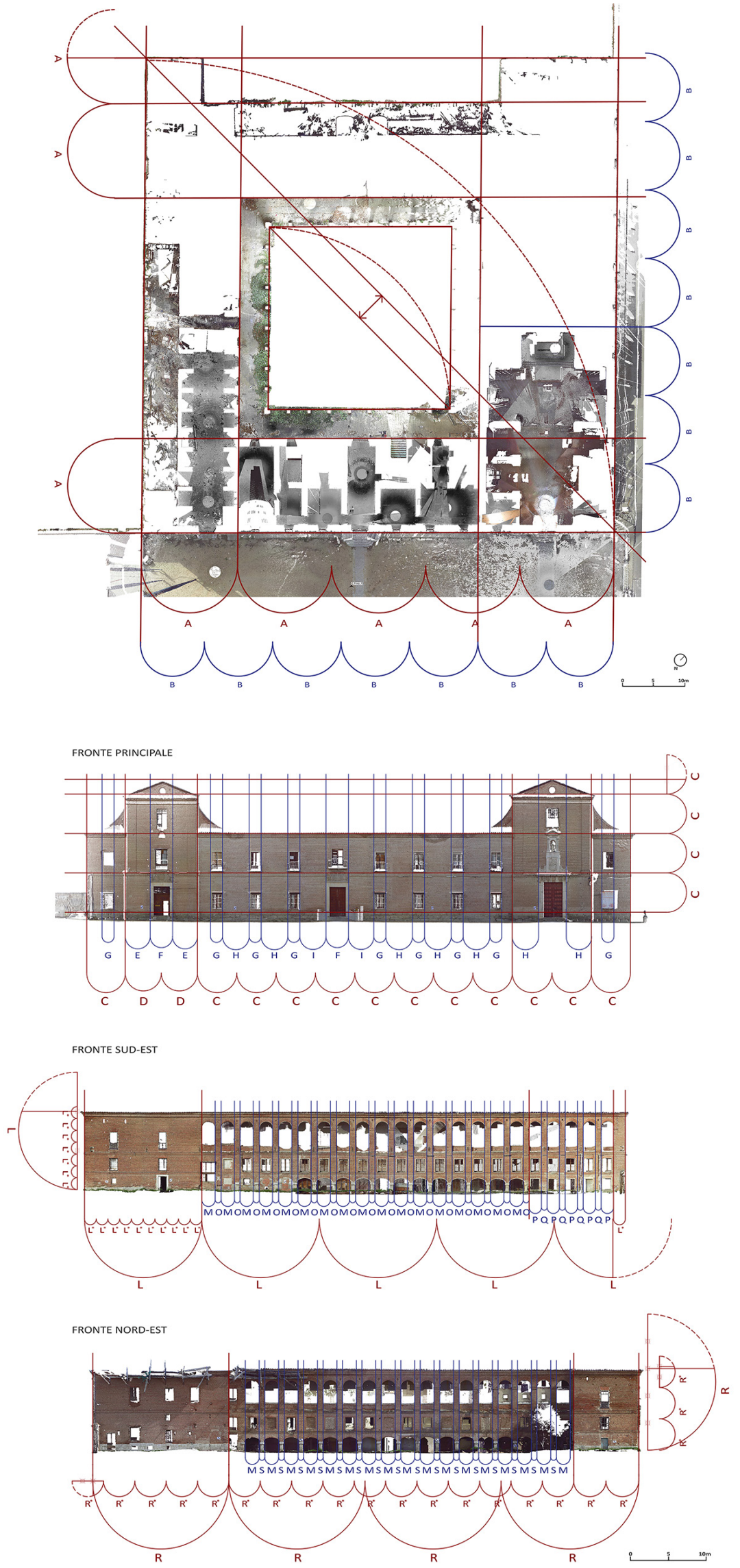
Fig. 6. Alignment, in the project environment of the doors and windows' familics according to the three-dimensional view and elevation.

Fig. 7. South-East front $\mathrm{H}$-BIM modeling process.
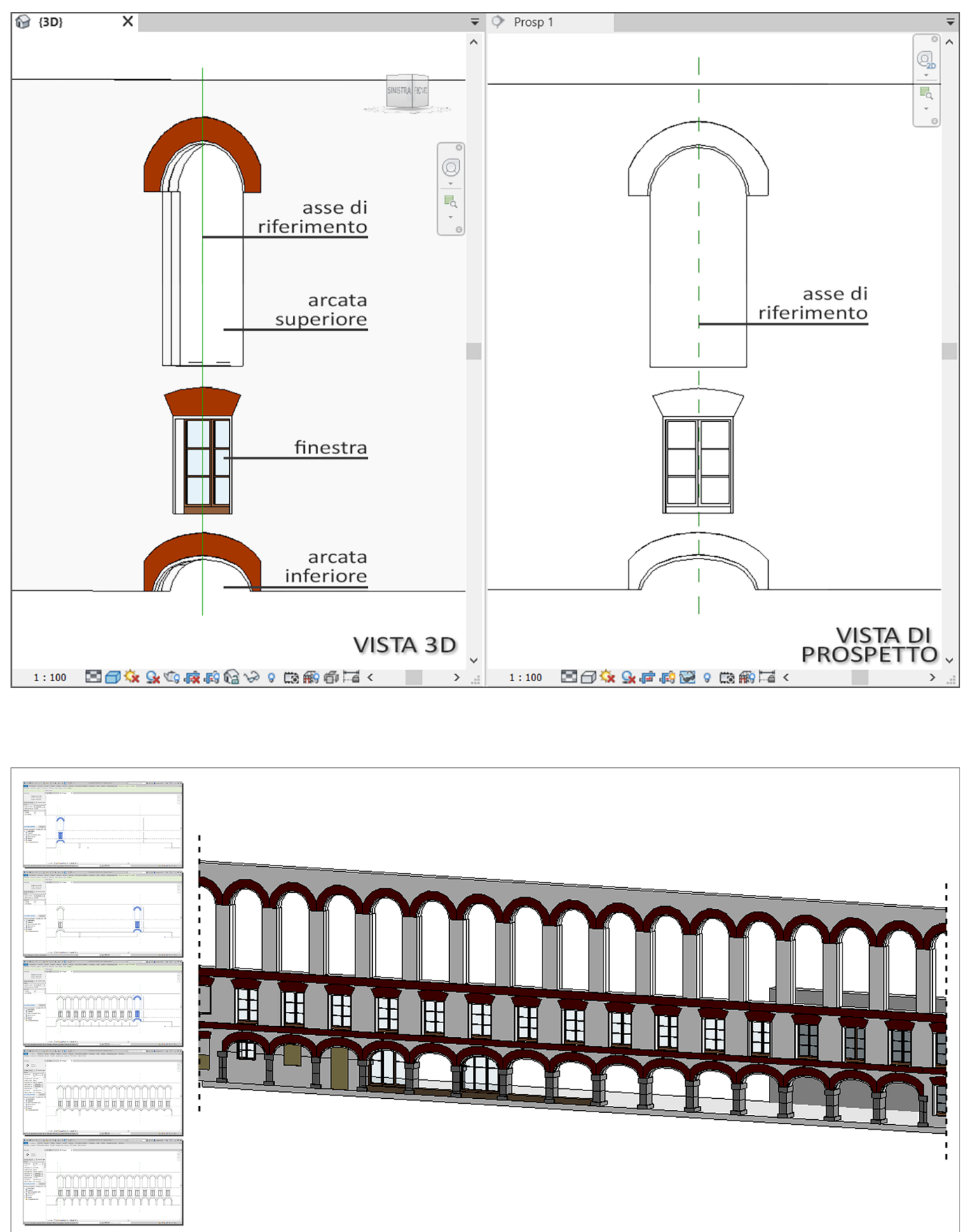


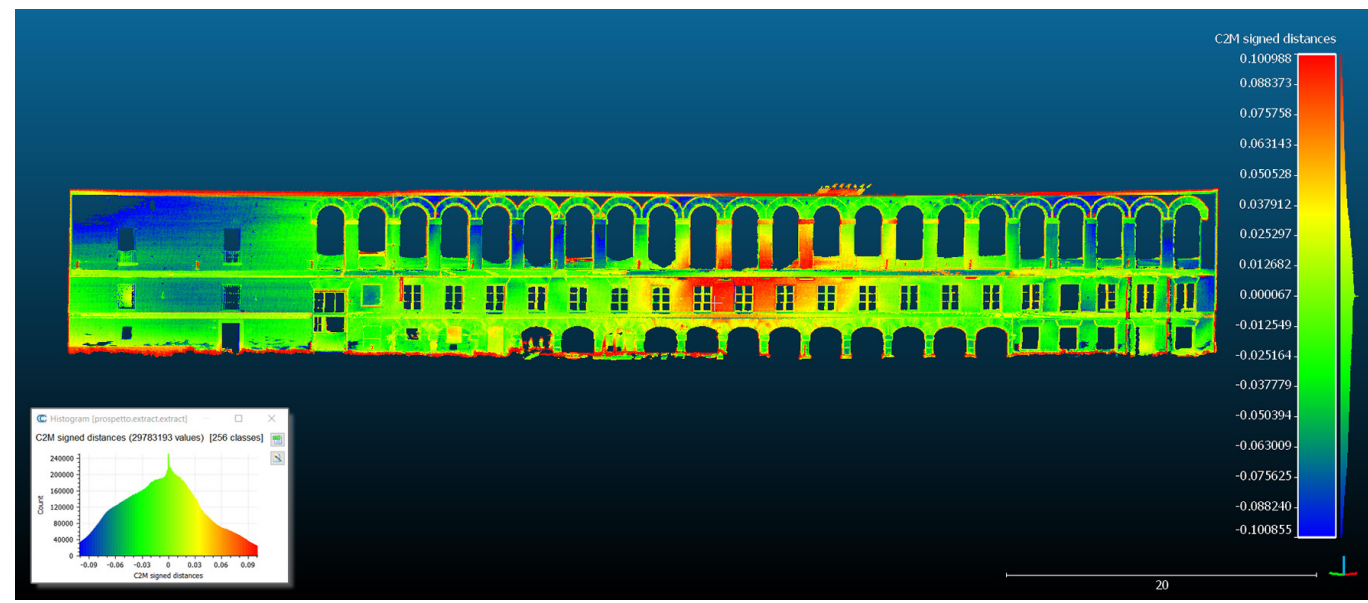

phases, apparently distinct and separate. A first, intended for the return of the reality-based survey through the $\mathrm{H}$-BIM modeling, managed by identifying the compositional rules of the artefact. The second, however, which relates the information model with the most current virtual fruition techniques, identifying the one that best lends itself to managing the different levels of reading that an information model allows. Future research developments are focused on this phase, in order to extend knowledge of the artefact, exemplified by Simón Ruiz Hospital, up to tracing its constitutive rules without, however, losing all the information associated with it. In this perspective, it is in the H-BIM model that the link between the point cloud and the virtual fruition is identified, making the whole only process.
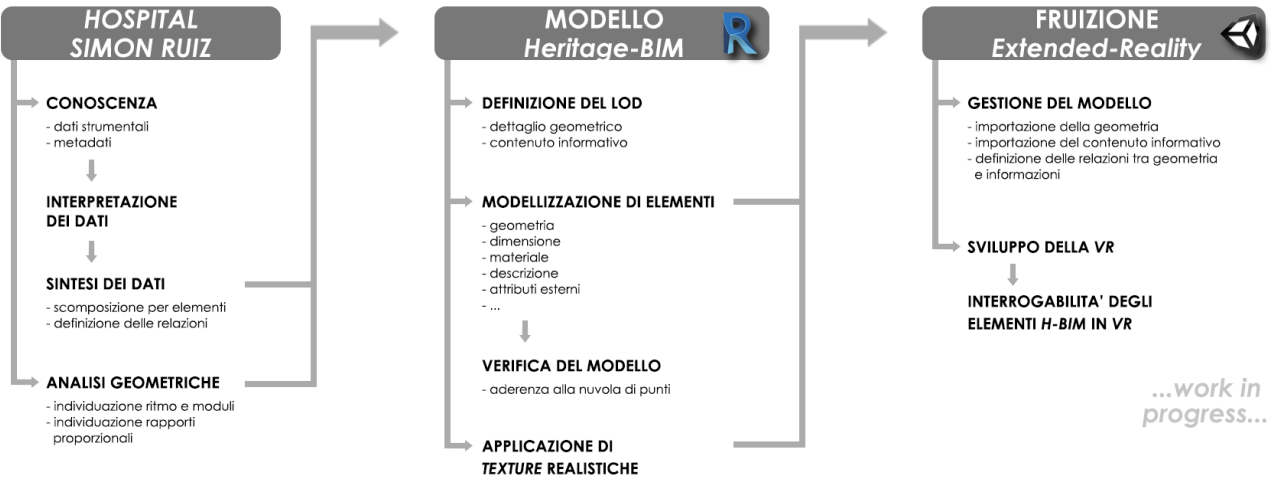

... work in progress..

Brumana Raffaella, Della Torre Stefano, Oreni Daniela, Previtali Mattia, Cantini Lorenzo, Barazzetti, Luigi, Franchi Alberto, Banfi Fabrizio (20/7). HBIM challenge among the paradigm of complexity, tools and preservation: The Basilica di Collemaggio 8 years after the earthquake (L'Aquila). In The International Archives of the Photogrammetry, Remote Sensing and Spatial Information Sciences, XLII-2/W5, 2017, pp. 97-104.

Davidson Jordan, Fowler John, Pantazis Charalampos, Sannino Massimo, Walker Jordan, Sheikhkhoshkar Moslem, Rahimian Farzad Pour (2019). Integration of VR with BIM to facilitate real-time creation of bill of quantities during the design phase: a proof of concept study. In Frontiers of Engineering Management, 20 I9, pp. I-8. 
Di Luggo Antonella, Palomba Daniela, Pulcrano Margherita, Scandurra Simona (2019). Theoretical and Methodological Implications in the Information Modelling of Architectural Heritage. In Bolognesi Cecilia Maria, Santagati Cettina (eds.). Impact of Industry 4.0 on Architecture and Cultural Heritage. United States of America: IGl Global editore, pp. 20-48.

Empler Tommaso, Caldarone Adriana, Fusinetti Alexandra (2019). Leonardo da Vinci: divulgazione delle sue opere attraverso i Serious Game. In Paolo Belardi (a cura di). Riflessioni. L'arte del disegno/il disegno dell'arte. Atti del $41^{\circ}$ Convegno Internazionale dei Docenti delle Discipline della Rappresentazione. Perugia 19-2 I Settembre 20 I 9. Roma: Gangemi editore, pp. I553- I562.

Fai Stephen, Rafeiro Jesse (20I4). Establishing an appropriate Level of Detail (LOD) for a Building Information Model (BIM)West Block, Parliament Hill, Ottawa, Canada. In ISPRS Annals of the Photogrammetry, Remote Sensing and Spatial Information Sciences, II-5, 2014, pp. I23-130.

Mann Steve, Furness Tom, Yuan Yu, lorio Jay, Wang Zixin (20।8). All Reality:Virtual, Augmented, Mixed (X), Mediated (X,Y), and Multimediated Reality. In ArXiv, Aprile, 8, 2018.

Navarro García Luis (1998). El Hospital General de Simón Ruiz en Medina del Campo: Fábrica e Idea. Salamanca: Junta de Castilla y Leon.

Pulido Serrano Juan Ignacio (2017). Más que negocios: Simón Ruiz, un banquero español del siglo XVI entre las penínsulas ibérica e italiana. S.L.: Iberoamericana Editorial Vervuert.

\section{Author}

Margherita Pulcrano, Università degli Studi di Napoli “Federico II”, margherita.pulcrano@unina.it

To cite this chapter. Pulcrano Margherita (2020). Modelli digitali interconnessi per ampliare la conoscenza e migliorare la fruizione del patrimonio costruito/Digital models interconnected to expand knowledge and improve the use of cultural heritage. In Arena A., Arena M., Brandolino R.G. Colistra D., Ginex G., Mediati D., Nucifora S., Raffa P. (a cura di). Connettere. Un disegno per annodare e tessere. Atti del $42^{\circ}$ Convegno Internazionale dei Docenti delle Discipline della Rappresentazione/Connecting. Drawing for weaving relationships. Proceedings of the 42th International Conference of Representation Disciplines Teachers. Milano: FrancoAngeli, pp. 2604-2621. 